\title{
HPLC Analysis of Glycosylated Amino Acids
}

\author{
Vanessa L. Campo, Áurea D. L. Borges and Ivone Carvalho* \\ Faculdade de Ciências Farmacêuticas de Ribeirão Preto, Departamento de Ciências Farmacêuticas, \\ Universidade de São Paulo, Av. Do Café, s/n, 14040-903 Ribeirão Preto-SP, Brazil
}

\begin{abstract}
Este trabalho descreve a padronização de metodologia de análise CLAE para identificação e separação dos aminoácidos glicosilados (blocos de construção) 3, 4, 7 e 8, e seus respectivos precursores. Os aminoácidos glicosilados, contendo unidades de açúcar $\beta$-D-GlcNAc (3 e 7) $O$ ligadas a aminoácidos de treonina estão envolvidos em eventos de sinalização celular, e os correspondentes isômeros 4 e 8, contendo unidades de $\alpha$-D-GlcNAc, estão relacionados a $O$ glicanas encontradas em mucinas do parasita Trypanosoma cruzi. A metodologia desenvolvida é vantajosa e eficiente, pois permite a análise de misturas reacionais brutas, evitando exaustivos processos de purificação.
\end{abstract}

This work describes the standardization of HPLC analysis methodology for the identification and separation of the glycosylated amino acids (building blocks) 3, 4, 7 and 8 and their respective precursors. The glycosylated amino acids containing the sugar units $\beta$-D-GlcNAc ( 3 and 7) $O$ linked to threonine amino acids are involved in cellular signalling events, and the correspondent isomers 4 and $\mathbf{8}$, possessing $\alpha$-D-GlcNAc units are related to $O$-glycans found in mucins of the parasite Trypanosoma cruzi. The developed methodology is advantageous and efficient as it permits the analysis of crude reaction mixtures, avoiding exhaustive purification processes.

Keywords: glycosylated amino acids, glycosylation reaction, HPLC

\section{Introduction}

It is at present well established that glycoproteins have been implicated in processes as varied as the immune response, proper intracellular targeting, intercellular recognition and protein folding, stability and solubility. Glycosylation is potentially the most complex category of protein modification reactions in eukaryotic systems and a remarkable degree of diversity is introduced due to the wide array of available glycosylated amino acids (monosaccharide building blocks). Most glycoproteins are not uniform, but consist of various "glycoforms", differing in type length, branching and number of site glycosylation. So, the isolation of glycoproteins from natural sources is therefore highly challenging and the range of glycoproteins that can be obtained in pure form is severely limited. ${ }^{1} O$-glycosylated amino acids, containing the sugar unit $O$-GlcNAc attached to serine or threonine amino acids, are constituents of some of these glycoproteins and are of utmost importance, since they are involved in recognition and cellular invasion processes.

* e-mail: carronal@usp.br
Recently, the occurrence of 2-acetamido-2-deoxy- $\beta$-Dglucopyranose ( $\beta$-D-GlcNAc) residues $O$-glycosidically linked to serine (1) or threonine (2) has been reported as a novel type of post-translational modification of intracellular proteins (Figure 1). The $O$-linked GlcNAc moieties are highly abundant on a number of intracellular proteins predominantly localized within the nucleo- and cytoplasmatic compartments of eukaryotic cells. $O$-GlcNAcSer/Thr bearing proteins are furthermore found in a wide range of nuclear oncogenes, chromatin proteins, nuclear pore proteins, cytoskeletal and viral proteins, including transcriptional regulatory factors, kinases and tyrosine phosphatases. ${ }^{2-4}$ There is also evidence of a link between $O$-GlcNAc modification and neuronal pathology, diabetes and other biological processes. ${ }^{3,4}$

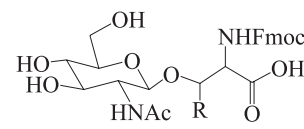

(1) $\mathrm{R}=\mathrm{H}$

(2) $\mathrm{R}=\mathrm{CH}_{3}$

Figure 1. Chemical structures of $\beta$-D-GlcNAc-Ser (1) and $\beta$-D-GlcNAcThr (2). 
A reciprocal relationship between $O$-GlcNAc glycosylation and phosphorylation has been reported owing to the post-translational $O$-GlcNAc modification of intracellular proteins that may be crucial in blocking site-specific phosphorylation. Three features suggest that $O$-GlcNAc plays an analogous role to protein phosphorylation in cellular regulation: (i) like phosphorylation, $O$-GlcNAc is highly dynamic with rapid cycling in response to cellular signals or cellular stages; (ii) $O$-GlcNAc occurs at sites on the protein backbone that are similar to those modified by protein kinases; (iii) $O$-GlcNAc is reciprocal with phosphorylation on some well-studied proteins, such as RNA Pol II, estrogen receptor- $\beta$ and the $\mathrm{c}-\mathrm{Myc}$ proto-oncogene product. These data are based on the 'Yin-Yang' hypothesis, which is achieved by blocking the site of phosphorylation due to the modification of an adjacent site by $O$-GlcNAc, or vice-versa (Figure 2). Differently modified proteins may perform different functions or be regulated by swapping between modification states, which involve the following statements: the protein must be deglycosylated before phosphorylation can occur, or the protein is dephosphorylated before glycosylation. ${ }^{3-6}$ According to this theory, the glycosylated amino acid $\beta$-D-GlcNAc-Ser/ $\mathrm{Thr}$ is of major importance considering its role in protein signalling and consequent cellular regulation.

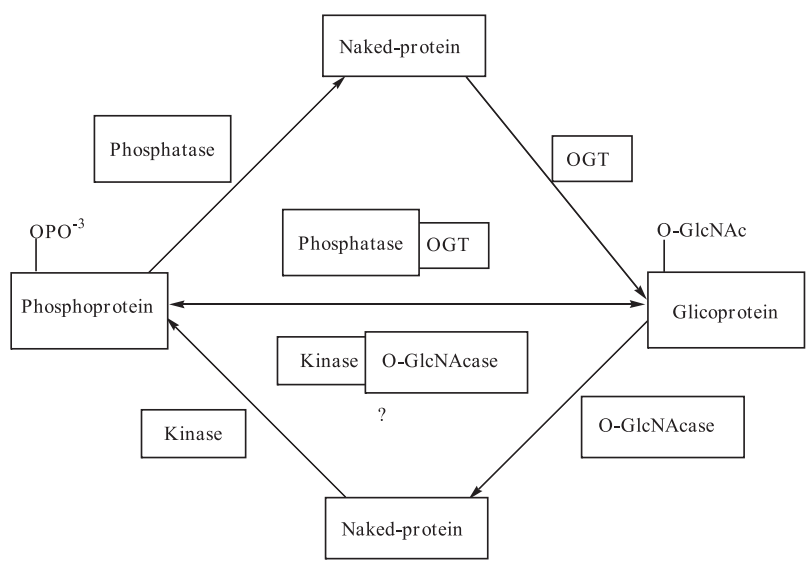

Figure 2. O-GlcNAc model of Yin-Yang hypothesis, capable to inhibit protein phosphorylation and vice-versa. OGT: $O-\beta-N$-acetylglucosaminyltransferase; O-GlcNAcase: $O-\beta-N$-acetyl-glucosaminidase.

A different approach involving glycosylated amino acids $O$-GlcNAc-Ser/Thr is concerned to $O$-glycans found in mucins of the parasite Trypanosoma cruzi. They contain a peptide backbone (rich in threonine sequence) $O$-linked to galactosyl residues through the $\alpha$-GlcNAc residue (Figure 3). ${ }^{7,8}$

The intracellular parasite T. cruzi, the causative agent of Chagas'disease, sheds a developmentally regulated surface

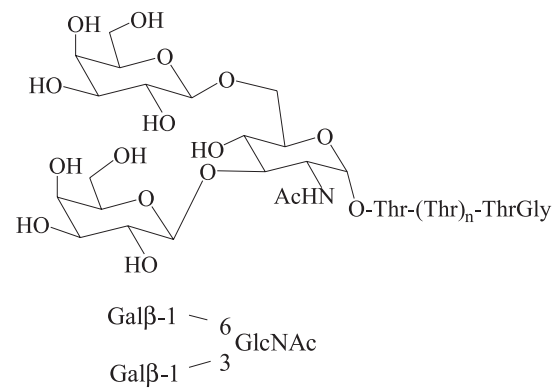

Figure 3. Example of glycan structure found in T.cruzi mucin molecule.

trans-sialidase which is involved in interactions between host cells and parasite that are crucial for cellular invasion and infection. T. cruzi can not synthesize sialic acid itself and uses a trans-sialidase enzyme to scavenge this monosacharide from host glycoconjugates to sialylate galactosyl molecules present in glycosylphosphatidylinositol (GPI)-anchored mucins (Figure 4).$^{7-9}$ Instead of using the common $\beta$-GlcNAc isomer found in cellular signalling, this process may involve the correspondent $\alpha$-GlcNAc isomer. Since the galactosyl residues are the site of the sialylation in mucin parasite membrane, this mechanism represents an important target for drugs design.

The construction of glycopeptides involves the coupling of glycosylated amino acids ( $\beta$-GlcNAc-Ser/Th and $\alpha$ GlcNAc-Ser/Thr) to a peptide backbone, normally performed in solid support. ${ }^{10}$ This procedure affords the isolation of interesting mimic glycopeptides to be employed in biological assays as artificial substrates/ inhibitors.

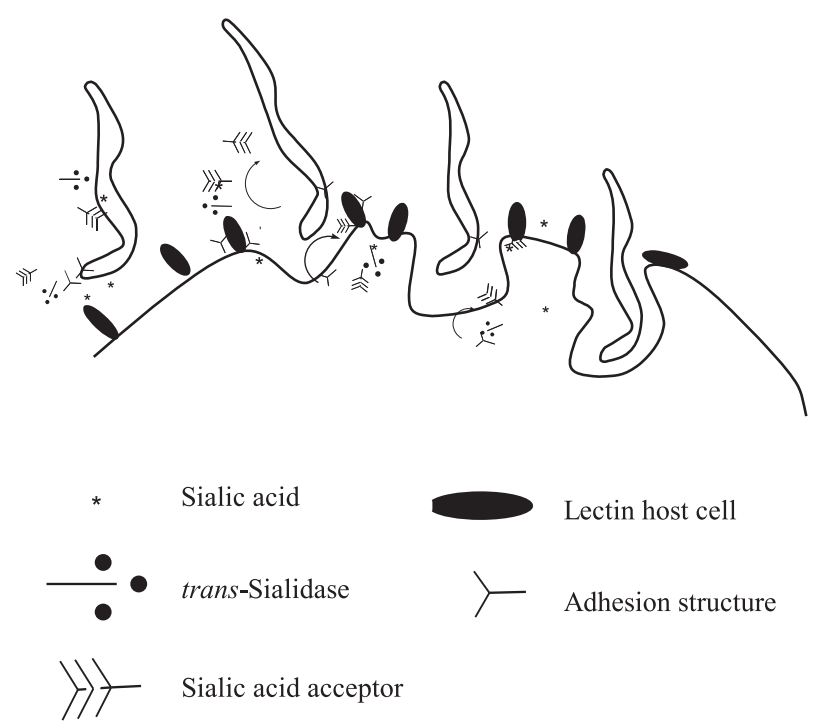

Figure 4. Process of invasion of T. cruzi to the host cell; the transfer of sialic acid from host to the parasite is indicated by arrows.

The preparation of glycosylated amino acids in high quantity is a challenge in carbohydrate synthesis. ${ }^{11-14}$ Depending on the precursors and promoters employed to 
generate the target compounds, the procedure may involve exhaustive successive purification processes allowing the unequivocal isomers characterization. The Nuclear Magnetic Resonance of ${ }^{1} \mathrm{H}$ and ${ }^{13} \mathrm{C}$ NMR analysis and Electro Spray Mass Spectrometry (ESI-MS) are the principal techniques to assess these compounds.

As an important tool in this process, HPLC represents an analytical method employed to the identification and purification of substances, occupying a worth place as a qualitative and quantitative technique. ${ }^{15}$ HPLC is also an advantageous and efficient method to be applied in organic synthesis, as it allows to follow up the chemical reactions, excluding the necessity of arduous chromatographic column purifications. It enables the analysis of crude reaction mixtures, once the analysis conditions have been standardized utilizing pure compounds previously.

According to the lack of information of glycosylated amino acids HPLC analysis, this work reports the standardization of the HPLC analysis conditions applied to the identification and separation of these compounds. Thus, the main purpose of this work is to develop a qualitative method to evaluate the rate of conversion of precursors, concerned to amino acids and donor sugar, into glycosylated amino acids of biological interest.

\section{Experimental}

\section{Synthesis of glycosylated aminoacids}

The glycosylated amino acids $\operatorname{FmocThrOBn}(O-\beta-\mathrm{D}$ GlcNAc) (3) and FmocThrOBn $(O-\alpha-\mathrm{D}-\mathrm{GlcNAc})(4)$ were synthesized, in solution, by the modified technique of Koenigs Knorr, ${ }^{12}$ through the glycosylation of the sugar 2 -acetamido-2-deoxy-3,4,6-tri- $O$-acetyl- $\alpha$-D-glucopyranosyl chloride (5), with the amino acid threonine (6), containing the protecting groups $N$-Fmoc (Fluoren-9ylmethoxycarbonyl) and $O$-Bn $(\mathrm{COOBn})$ (reaction 1$)$. The reaction was performed in the presence of $\mathrm{HgBr}_{2}$ (promoter) and 1,2-dichloroethane (solvent) and gave compounds 3 and 4 with yields of $48 \%$ and $18 \%$, respectively. The removal of $O$-benzylic ester protecting groups of compounds $\mathbf{3}$ and $\mathbf{4}$ by hydrogenolysis reaction ${ }^{16}$ $\left(10 \% \mathrm{Pd}-\mathrm{C} / \mathrm{H}_{2}\right)$ afforded the correspondent products FmocThrOH $(O-\beta-\mathrm{D}-\mathrm{GlcNAc})(7)$ and $\operatorname{FmocThrOH}(O-\alpha-$ D-GlcNAc) (8), both with $95 \%$ of yield (Scheme 1). The products $\mathbf{7}$ and $\mathbf{8}$ were also prepared by the glycosylation reaction of the sugar 5 with the amino acid FmocThrOH (9) (reaction 2). Although the reaction with the amino acid 9, containing free carboxylic group, avoids two synthetic steps, one involving the protection of the carboxylic group and other the deprotection of this group (hydrogenolysis), it is not so trivial, as the purification of the formed products is very difficult.

\section{Structural characterization}

2-acetamido-2-deoxy-3,4,6-tri-O-acetyl- $\alpha$-D-glucopyranosyl chloride $(5) . \delta_{\mathbf{H}}\left(\mathrm{CDCl}_{3} ; 400 \mathrm{MHz}\right) 6.21(1 \mathrm{H}$, d, $\left.J_{1,2} 3.6 \mathrm{~Hz}, \mathrm{H}-1\right), 5.88(1 \mathrm{H}, \mathrm{d}, J 8.4 \mathrm{~Hz}, \mathrm{NH}), 5.35(1 \mathrm{H}$, t, $J 10.0 \mathrm{~Hz}, \mathrm{H}-3$ or H-4), 5.25 (1H, t, $J 10,0 \mathrm{~Hz}, \mathrm{H}-3$ or $\mathrm{H}-4), 4.55$ (1H, ddd, $J_{4,5} 10.0 \mathrm{~Hz}, J_{5,6} 3.6 \mathrm{~Hz}, J_{5,6}{ }^{\prime} 1.5 \mathrm{~Hz}$, H-5), 4.33-4.26 (2H, m, H-6, H-6'), 4.14 (1H, dd, $J_{2,3} 10.0$ $\left.\mathrm{Hz}, J_{1,2} 3.6 \mathrm{~Hz}, \mathrm{H}-2\right), 2.20-1.93$ (12H, m, 4xCH $\mathrm{CO}$ ).

$N$-(9-Fluorenylmethoxycarbonyl-L-threonine benzyl ester (6). $\delta_{\mathrm{H}}\left(\mathrm{CDCl}_{3}, 400 \mathrm{MHz}\right) 7.80(2 \mathrm{H}, \mathrm{d}, J 7.5 \mathrm{~Hz}, \mathrm{CH}$ Fmoc arom.), 7.59 (2H, d, J 7.5 Hz, CH Fmoc arom.), 7.437.21 (9H, m, CH benzyl, Fmoc arom), 5.62 (1H, d, J 9,3 $\mathrm{Hz}, \mathrm{NH}), 5.22\left(2 \mathrm{H}, \mathrm{AB}, J_{\mathrm{AB}} 12.2 \mathrm{~Hz}, \mathrm{CH}_{2}\right.$ benzyl), 4.42.(2H, m, CH Thr), 4.37 ( $2 \mathrm{H}, \mathrm{m}, \mathrm{CH}_{2}$ Fmoc), 4.22 $(1 \mathrm{H}, \mathrm{t}, J 6.9 \mathrm{~Hz}, \mathrm{CH}$ Fmoc), 1.65 (1H, br s, OH), 1.22 $\left(3 \mathrm{H}, \mathrm{d}, \mathrm{J} 6.0 \mathrm{~Hz}, \mathrm{CH}_{3}\right)$.

$N$-(9-Fluorenylmethoxycarbonyl-L-threonine (9). $\delta_{\mathbf{H}}\left(\mathrm{CDCl}_{3}\right.$, $400 \mathrm{MHz}) 7.80$ (2H, d, J 7.5 Hz, CH Fmoc arom.), 7.59 (2H, d, J 7,5 Hz, CH Fmoc arom.), 7.43-7.21 (4H, m, CH Fmoc arom), 5.62 (1H, d, J 9.3 Hz, NH), 4.42.(2H, m, CH Thr), 4.37 (2H, m, $\mathrm{CH}_{2}$ Fmoc), 4.22 (1H, t, J $6.9 \mathrm{~Hz}, \mathrm{CH}$ Fmoc), 1.65 (1H, br s, OH), $1.22\left(3 \mathrm{H}, \mathrm{d}, J 6.0 \mathrm{~Hz}, \mathrm{CH}_{3}\right)$.

$N$-(9-Fluorenylmethoxycarbonyl-(2-acetamido-2-deoxy3,4,6-tri-O-acetyl- $\beta$-D-glucopyranosyl) L-threonine benzyl ester (3). $\delta_{\mathbf{H}}\left(\mathrm{CDCl}_{3}, 400 \mathrm{MHz}\right) 7.70(2 \mathrm{H}, \mathrm{d}, J 7.3 \mathrm{~Hz}, \mathrm{CH}$ Fmoc arom.), 7.57 (2H, d, J 7.8 Hz, CH Fmoc arom.), 7.357.20 (9H, m, CH benzyl and Fmoc arom.), 5.80 (1H, d, $J$ $9.6 \mathrm{~Hz}, \mathrm{NH}$ Thr), 5.45 (1H, d, J 8,5 Hz, NHAc), $5.20(1 \mathrm{H}$, t, J10.1 Hz, H-3), 5.15, 5.10 (2H, AB, J ${ }_{\mathrm{AB}} 12.2 \mathrm{~Hz}, \mathrm{CH}_{2}$ benzyl), $4.95(1 \mathrm{H}, \mathrm{t}, J 10,1 \mathrm{~Hz}, \mathrm{H}-4), 4.60\left(1 \mathrm{H}, \mathrm{d}, J_{1,2} 8,1\right.$ $\mathrm{Hz}, \mathrm{H}-1)$, 4.41-4.35 (3H, m, $\mathrm{CH}_{2}$ Fmoc, $\beta \mathrm{CH}$ Thr), 4.30 (1H, dd, J 7.3 Hz, J 10.6 Hz, $\alpha \mathrm{CH}$ Thr), 4.18 (1H, t, $J 7.3$ $\mathrm{Hz}, \mathrm{CH}$ Fmoc), 4.12 (1H, dd, $J_{5,6} 4.3 \mathrm{~Hz}, J_{6,6}, 12,3 \mathrm{~Hz}, \mathrm{H}-$ 6), 3.95 (1H, dd, $J_{5,6}, 2.2 \mathrm{~Hz}, J_{6,6}, 12.3 \mathrm{~Hz}, \mathrm{H}-6$ '), $3.60(1 \mathrm{H}$, dd, $\left.J_{1,2} 8,1 \mathrm{~Hz}, J_{2,3} 10,1 \mathrm{~Hz}, \mathrm{H}-2\right), 3.45-3.38$ (1H, m, H-5), $1.98,1.96,1.92,1.88\left(12 \mathrm{H}, 4 \mathrm{~s}, 4 \mathrm{x} \mathrm{COCH}_{3}\right), 1.10(3 \mathrm{H}, \mathrm{d}, J$ 6.0 Hz, $\mathrm{CH}_{3}$ Thr). ESI-MS- $m / z 778.3187\left[\mathrm{M}+\mathrm{NH}_{4}^{+}\right]$.

$N$-(9-Fluorenylmethoxycarbonyl-(2-acetamido-2-deoxy3,4,6-tri-O-acetyl- $\alpha$-D-glucopyranosyl)-L-threonine benzyl ester (4). $\delta_{\mathbf{H}}\left(\mathrm{CDCl}_{3}, 400 \mathrm{MHz}\right) 7.77(2 \mathrm{H}, \mathrm{d}, J 7.5, \mathrm{CH}$ Fmoc arom.), 7.64 (2H, d, J 6.0, CH Fmoc arom.), 7.497.26 (9H, m, CH benzyl and Fmoc arom.), 5.94 (1H, d, $J$ 9.3, NHAc), 5.73 (1H, d, J 9.5, NHThr), 5.20-5.14 (1H, m, 
H-3), 5.19, 5.09 (2H, AB, $J_{\mathrm{AB}} 12.2 \mathrm{~Hz}, \mathrm{CH}_{2}$ benzyl), 5.08 (1H, t, $\left.J_{3,4} 9.4, \mathrm{H}-4\right), 4.61\left(1 \mathrm{H}, \mathrm{d}, J_{1,2} 3.6, \mathrm{H}-1\right), 4.55-4.44$ $\left(3 \mathrm{H}, \mathrm{m}, \mathrm{CH}_{2}\right.$ Fmoc, $\left.\alpha \mathrm{CHThr}\right), 4.31-4.07$ (5H, m, $\beta \mathrm{CHThr}$, CHFmoc, H-2, H-6, H-6'), 4.01-3.97 (1H, m, H-5), 2.06, 2.04, 2.03, $1.96\left(12 \mathrm{H}, \mathrm{s}, \mathrm{COCH}_{3}\right), 1.28\left(3 \mathrm{H}, \mathrm{d}, J\right.$ 6.2, $\mathrm{CH}_{3}$ Thr). ESI-MS- $m / z 761.2938\left[\mathrm{M}+\mathrm{H}^{+}\right]$

$N$-(9-Fluorenylmethoxycarbonyl-(2-acetamido-2-deoxy3,4,6-tri-O-acetyl- $\beta$-D-glucopyranosyl)-L-threonine (7). $\delta_{\mathrm{H}}\left(\mathrm{CDCl}_{3} / \mathrm{CD}_{3} \mathrm{OD}, 400 \mathrm{MHz}\right) 7.78(2 \mathrm{H}, \mathrm{d}, J 7.3 \mathrm{~Hz}, \mathrm{CH}$ Fmoc arom.), 7.65 (2H, d, $J$ 6,6 Hz, CH Fmoc arom.), 7.43-7.28 (4H, m, Fmoc arom.), $6.12(1 \mathrm{H}, \mathrm{d}, J 9.2 \mathrm{~Hz}$, $\mathrm{N} H \mathrm{Thr}), 6.03(1 \mathrm{H}, \mathrm{d}, J 9,2 \mathrm{~Hz}, \mathrm{NHAc}), 5.25\left(1 \mathrm{H}, \mathrm{t}, J_{2,3}\right.$ $9.6 \mathrm{~Hz}, \mathrm{H}-3), 5.00\left(1 \mathrm{H}, \mathrm{t}, J_{3.4} 9.6 \mathrm{~Hz}, \mathrm{H}-4\right), 4.65(1 \mathrm{H}, \mathrm{d}$, $\left.J_{1,2} 8.3 \mathrm{~Hz}, \mathrm{H}-1\right), 4.47-4.35$ (4H, m, $\mathrm{CH}_{2}$ Fmoc, 2CH Thr), $4.30(1 \mathrm{H}, \mathrm{dd}, J 6,8 \mathrm{~Hz}, J 10,6 \mathrm{~Hz}, \mathrm{H}-6), 4.20-4.00(2 \mathrm{H}$, m, CH Fmoc, H-6'), 3.85 (1H, dd, $J_{1,2} 8,1 \mathrm{~Hz}, J_{2,3} 10,1$ $\mathrm{Hz}, \mathrm{H}-2), 3.75$ (1H, m, H-5), 2.04, 1.98, 1.97, $1.93(12 \mathrm{H}$, 4s, 4 x $\left.\mathrm{COCH}_{3}\right), 1.20\left(3 \mathrm{H}, \mathrm{d}, J 6.3 \mathrm{~Hz}, \mathrm{CH}_{3}\right.$ Thr). ESI-MS$\mathrm{m} / \mathrm{z} 671.2453\left[\mathrm{M}+\mathrm{NH}_{4}^{+}\right]$.

$N$-(9-Fluorenylmethoxycarbonyl-(2-acetamido-2-deoxy3,4,6-tri-O-acetyl- $\alpha$-D-glucopyranosyl) L-threonine (8). $\delta_{\mathrm{H}}\left(\mathrm{CDCl}_{3}, 400 \mathrm{MHz}\right) 7.68(2 \mathrm{H}, \mathrm{d}, J 7.3 \mathrm{~Hz}, \mathrm{CH}$ Fmoc arom.), 7.55 (2H, d, $J$ 6,6 Hz, CH Fmoc arom.), 7.34$7.23(4 \mathrm{H}, \mathrm{m}, \mathrm{Fmoc}$ arom.), $6.44(1 \mathrm{H}, \mathrm{d}, J$ 8.9, NH), 6.11 $(1 \mathrm{H}, \mathrm{d}, J 9.7, \mathrm{NH}), 5.09\left(1 \mathrm{H}, \mathrm{t}, J_{2,3} 10.0, \mathrm{H}-3\right), 5.01(1 \mathrm{H}, \mathrm{t}$, $\left.J_{3,4} 9.5, \mathrm{H}-4\right), 4.94$ (1H, d, $\left.J_{1,2} 3.4, \mathrm{H}-1\right), 4.60-3.90$ (9H, m, $\mathrm{CH}_{2}$ Fmoc, $2 \mathrm{CH}$ Thr, H-6, CH Fmoc, H-6', H-2, H-5), $2.01,2.00,1.99,1.96\left(12 \mathrm{H}, \mathrm{s}, \mathrm{COCH}_{3}\right), 1.28(3 \mathrm{H}, \mathrm{d}, J$ 6.7, $\mathrm{CH}_{3}$ Thr). ESI-MS- $\mathrm{m} / 2671.2453\left[\mathrm{M}+\mathrm{NH}_{4}^{+}\right]$.

HPLC analysis

All the solvents utilized were of HPLC grade (Mallinckrodt), previously filtered in $0.45 \mu \mathrm{m}$ Millipore membrane. The deionized water was of Milli-Q Plus System (Millipore, USA). The chromatographic analyses were carried out on a Shimadzu Liquid Chromatography, composed by two pumps (model LC6AD), a system Controller SCL-10A, column oven CTO-6AS, a SPD-M10 A diode array detector (1 225 $\mathrm{nm})$ and a 7725 Rheodyne injector with a $20 \mu \mathrm{L}$ loop. Separations were performed under isocratic conditions on a Shim-PacK CLC-ODS (M) column $(250 \times 4.6 \mathrm{~mm}$, $5 \mu \mathrm{m}$ particles size $)$ at $25^{\circ} \mathrm{C}$. A guard column $(1 \mathrm{~cm} \times$ $4 \mathrm{~mm}$, I. D., Shimadzu, Japan) of the same material was used to protect the analytical column.

The mobile phase constituted by acetonitrile-water (70:30

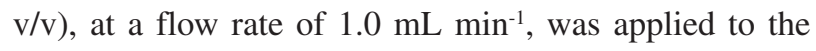
compounds $3,4,5$ and 6 , and the mobile phase constituted by methanol-acetonitrile-water $(50: 20: 30 \mathrm{v} / \mathrm{v} / \mathrm{v})$, at a flow rate of $0.8 \mathrm{~mL} \mathrm{~min}^{-1}$, was employed to the compounds $5,7,8$ and 9 . The water of the mobile phases had its $\mathrm{pH}$ adjusted to 2.7 by the addition of trifluoracetic acid. The mobile phases were, then, filtered in $0.45 \mu \mathrm{m}$ Millipore membrane and degassed during $10 \mathrm{~min}$ before use. The samples were dissolved in the respective mobile phases at concentration of $1.0 \mathrm{mg} \mathrm{mL}^{-1}$, swirled in mixer and filtered in $0.45 \mu \mathrm{m}$ Millipore membrane. Samples of $20 \mu \mathrm{L}$ were injected in the HPLC system and the analyses were performed during $30 \mathrm{~min}$. The data were integrated by the "software" Shimadzu CLASS-VP 5.03.

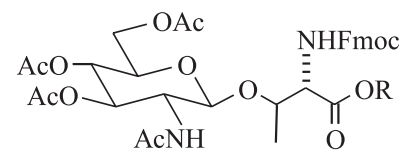

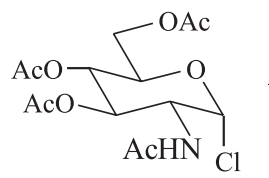

(5)

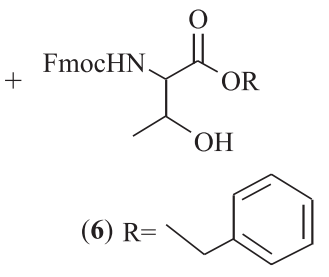

(9) $\mathrm{R}=\mathrm{H}$
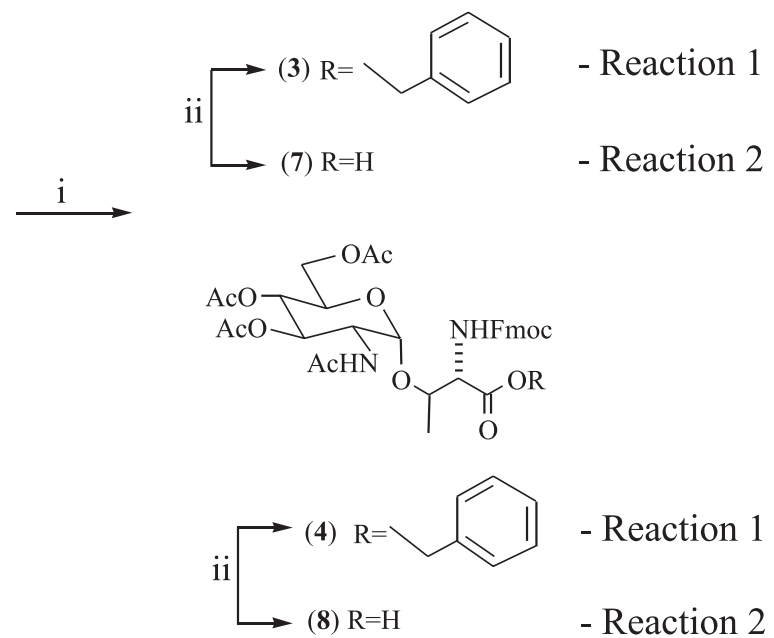

Scheme 1. Synthetic procedure to prepare the glycosylated aminoacids 3, 4, 7 and $\mathbf{8}$. i: $\mathrm{HgBr}_{2} / 1$,2-dichloroethane. ii: $10 \% \mathrm{Pd}-\mathrm{C} / \mathrm{H}_{2} / \mathrm{methanol} / \mathrm{AcOH}$. 


\section{Results and Discussion}

The glycosylation reaction between the glycosyl donor $\beta$-D-GlcNAcCl (5) and the amino acid FmocThrOBn (6) afforded the products 3 ( $\beta$ isomer) and 4 ( $\alpha$ isomer), $\beta / \alpha$ 4:1 (Scheme 1). Depending on the reflux time, it was evident the major generation of the $\alpha$ isomer, obtained in a proportion of 1:1, after approximately 60 hours. The products were separated and purified by silica gel chromatographic column [ethyl acetate-hexane 7:3 (v/v)]. The compounds $\mathbf{3}$ and $\mathbf{4}$ was characterized by NMR ${ }^{1} \mathrm{H}$ analysis; the chemical shift of the anomeric $\mathrm{H}-1$ of $\mathbf{3}$ was found at $\delta 4.60, J_{1,2} 8.1 \mathrm{~Hz}$, while correspondent $\mathrm{H}-1$ of the $\alpha$ isomer, deshielded than $\mathbf{3}$, was observed at $\delta 4.94$, $J_{1,2} 3.4 \mathrm{~Hz}$. The glycosylated amino acids $\mathbf{7}$ and $\mathbf{8}$, obtained by hydrogenolysis of $\mathbf{3}$ and $\mathbf{4}$, and by direct glycosylation of 5 and $\mathbf{9}$ also displayed the same NMR ${ }^{1} \mathrm{H}$ profile.

The HPLC separation of all compounds was performed on the chromatographic column Shim-PacK CLC-ODS (M) with an isocratic method. Several analysis conditions were applied to the groups of compounds $3,4,5,6$, and $5,7,8,9$, involving distinct mobile phases, in different proportions and flow rate. Some of the mobile phases tested were methanol-
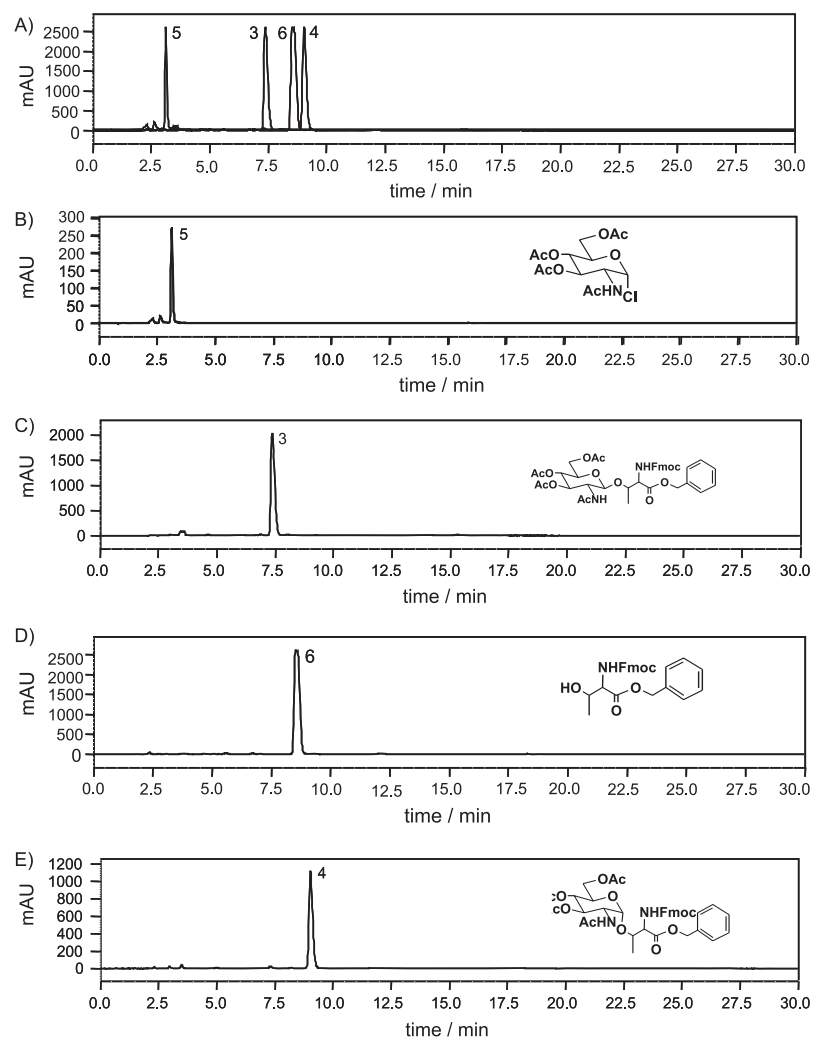

Figure 5. Chromatograms of HPLC analysis of pure compounds $\mathbf{3 , 4}, \mathbf{5}$ and 6. (A) Compounds 5, 3, 6 and 4, respectively; (B) $\beta$-D-GlcNAcCl (5); (C) FmocThrOBn $(O-\beta$-D-GlcNAc) (3); (D) FmocThrOBn (6); (E) FmocThrOBn $(O-\alpha-\mathrm{D}-\mathrm{GlcNAc})(\mathbf{4})$. acetonitrile-water (50:20:30), acetonitrile, methanolwater (80:20), methanol-water (70:30), and acetonitrilewater (80:20), at flow of $1.0 \mathrm{~mL} \mathrm{~min}^{-1}$; methanol-water (70:30), and acetonitrile-water (50:50), at flow of 0.8 $\mathrm{mL} \mathrm{min}^{-1}$; and methanol-water (70:30), at flow of 0.5 $\mathrm{mL} \mathrm{min}^{-1}$. However, considering the proximity of retention times between amino acids and products, these mobile phases were not efficient for the separation of the precursors $\mathbf{6}$ and $\mathbf{9}$ from their correspondent products 3 and 7. The deionized water of the mobile phases was of Milli-Q degree and acidified to $\mathrm{pH} 2.7$ with trifluoracetic acid before use. The column CLC-NH (M) was also used, but the separation of the compounds was not possible.

For the compounds $3,4,5$ and 6 , the isocratic elution with acetonitrile-water (70:30), at flow of $1.0 \mathrm{~mL} \mathrm{~min}^{-1}$ was the best condition to evaluate the optimal peak sharpness and efficient separation among them. On the other hand, evaluation of the precursors $\mathbf{5}$ and $\mathbf{9}$, and products $\mathbf{7}$ and $\mathbf{8}$, was very difficult according to close retention times between precursors and products. The best result was obtained by using the isocratic elution with methanol-acetonitrile-water (50:20:30 v/v/v), at a flow rate of $0.8 \mathrm{~mL} \mathrm{~min}{ }^{-1}$. Since the standardization
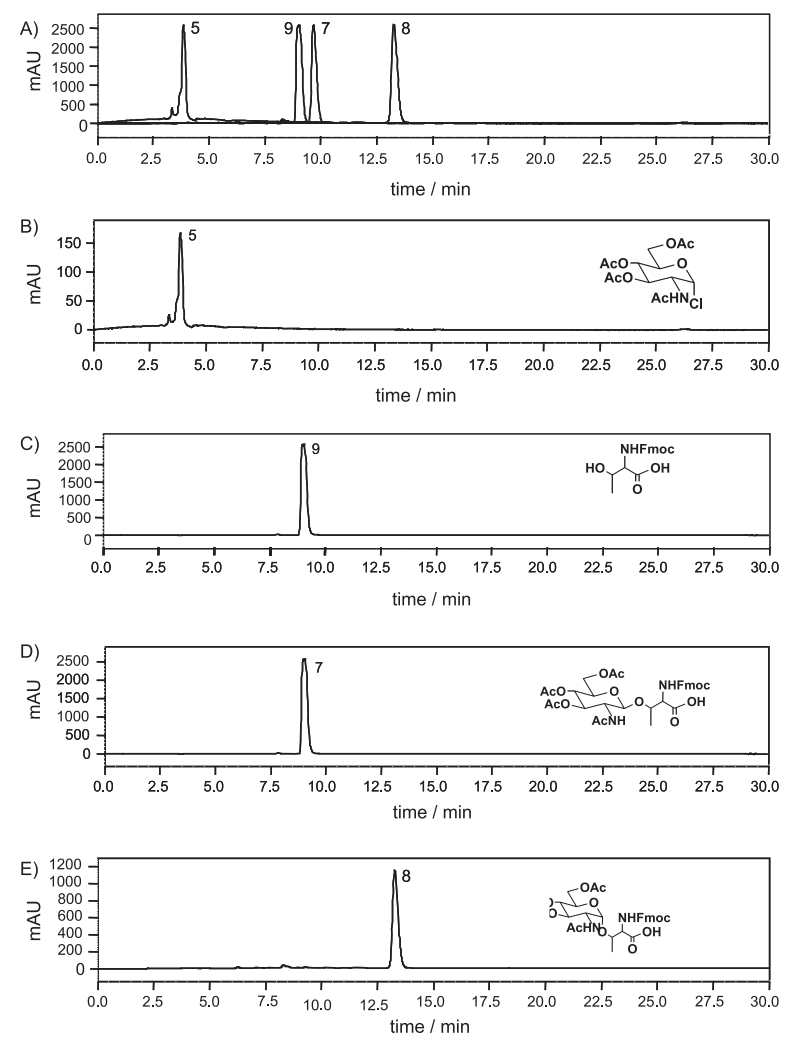

Figure 6. Chromatograms of HPLC analysis of the pure compounds $\mathbf{5}$, 7,8 and 9. (A) Compounds 5, 9, 7 and 8 , respectively; (B) $\beta$-D-GlcNAcCl

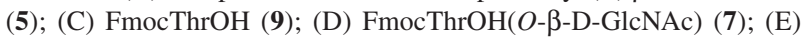
FmocThrOH $(O-\alpha-\mathrm{D}-\mathrm{GlcNAc})(\mathbf{8})$. 


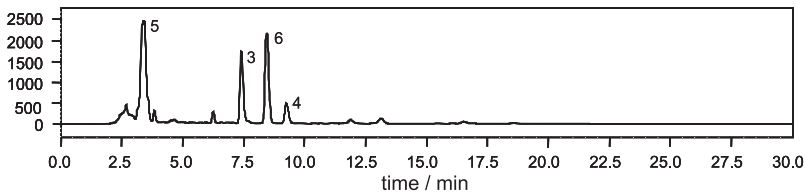

Figure 7. HPLC analysis of the crude reaction mixture related to the reaction 1 .

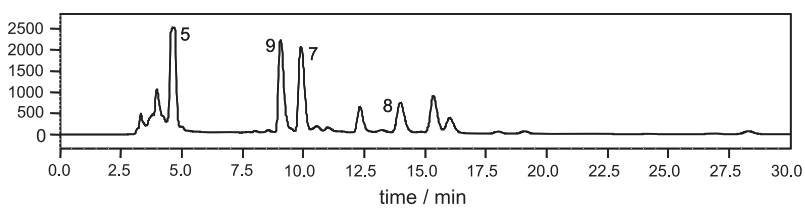

Figure 8. HPLC analysis of the crude reaction mixture related to the reaction 2 .

conditions were established, the next step was to join the purified precursors and products to evaluate them as a mixture and confirm the corresponding individual retention times for related compounds $\mathbf{3}, \mathbf{4}, \mathbf{5}, \mathbf{6}$, and $\mathbf{5}$, 7, 8, 9. The Figures 5 and 6 show separated chromatograms concerned to each group of compounds analysed, and single chromatograms containing the individual peaks of the precursors and final products, showing high resolution of the peaks, as follow: compounds 5/3: 19.6, 3/6: 3.2, 6/4: 1.3, 5/9:11.1, 9/7: 1.4, and 7/8: 5.8 .

The HPLC analysis of the crude reaction mixture correspondent to the formation of the products $\mathbf{3}$ and $\mathbf{4}$ (reaction 1) resulted in a chromatogram composed by distinct peaks related to the precursors and final products, with retention times very close to the pure samples (Figure 7). According to this analysis it was possible to observe the great consumption of the sugar $\mathbf{5}$ parallel to the formation of the desired products $\mathbf{3}$ and $\mathbf{4}$, in different proportions according to the reaction times. On the other hand, the chromatogram of the reaction mixture related to the formation of the products $\mathbf{7}$ and $\mathbf{8}$ (reaction 2), also allowed the identification of different peaks concerned to the precursors and final products, whose retention times were also almost similar to the pure compounds (Figure 8). Selectivity of the method was also confirmed by comparison of UV spectra of each compound as a pure or in a mixture sample. The detection limits, based on three times the noise level were $\beta$-D-GlcNAcCl (5): $250 \mu \mathrm{g} \mathrm{mL}^{-1}$, FmocThrOBn (6): $2,5 \mu \mathrm{g} \mathrm{mL}^{-1}$, FmocThrOBn( $O-\beta$-D-GlcNAc) (3): 25 $\mu \mathrm{g} \mathrm{mL}{ }^{-1}, \operatorname{FmocThrOH}(O-\alpha-\mathrm{D}-\mathrm{GlcNAc})(4): 55 \mu \mathrm{g} \mathrm{mL} \mathrm{m}^{-1}$, FmocThrOH(O- $\beta$-D-GlcNAc) (7): $25 \mu \mathrm{g} \mathrm{mL}^{-1}$ and FmocThrOH(O- $\alpha$-D-GlcNAc) (8): $100 \mu \mathrm{g} \mathrm{mL}^{-1}$.

Table 1. Retention times $\left(\mathrm{R}_{\mathrm{t}}\right.$ ) and percentual area (\%) values of HPLC analysis applied to the pure compounds and the components of the crude reaction mixture (reaction 1)

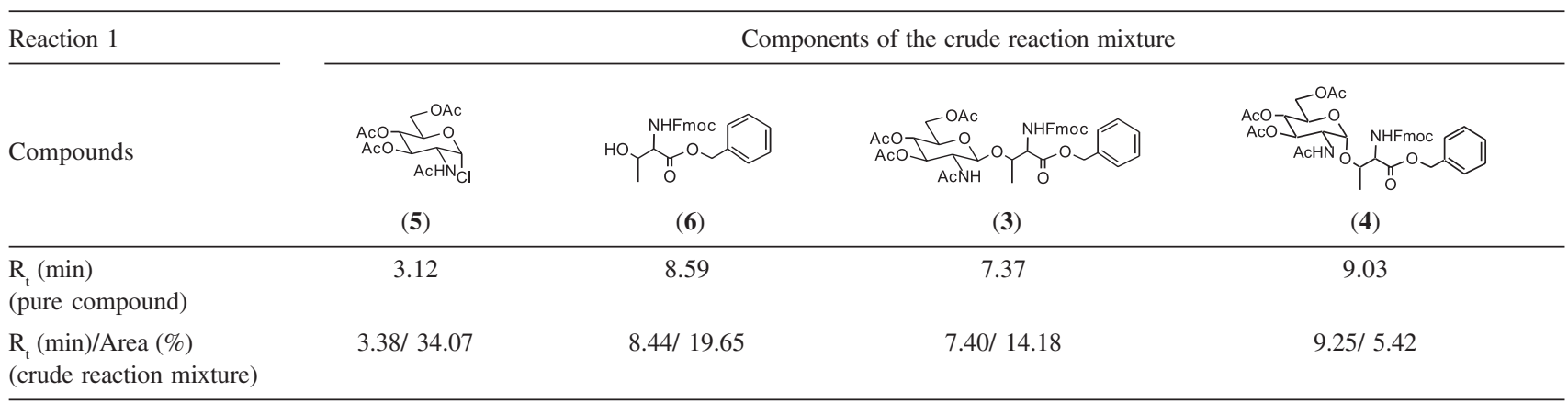

Table 2. Retention times $\left(\mathrm{R}_{\mathrm{t}}\right.$ ) and percentual area (\%) values of HPLC analysis applied to the pure compounds and the components of the crude reaction mixture (reaction 2)

\begin{tabular}{lcccc}
\hline Reaction 2 & \multicolumn{5}{c}{ Components of the crude reaction mixture } \\
\cline { 2 - 5 } Compounds & $(\mathbf{5})$ & $(\mathbf{9})$ & 9.68 & $(\mathbf{8})$ \\
\hline $\begin{array}{l}\mathrm{R}_{\mathrm{t}} \text { (min) } \\
\text { (pure compound) }\end{array}$ & 3.85 & 8.98 & $9.90 / 12.10$ & 13.97 \\
$\begin{array}{l}\mathrm{R}_{\mathrm{t}} \text { (min)/Area }(\%) \\
\text { (crude reaction mixture) }\end{array}$ & $3.98 / 8.85$ & $9.06 / 12.65$ & \\
\hline
\end{tabular}


The different retention times and the corresponding area percent $(\%)$ of the pure compounds and the components of the crude reaction mixtures, related to the reactions 1 and 2 , are illustrated in Tables 1 and 2, respectively. Since the compounds have amide bonds, the diode array detector was preferentially used at wavelengths around $225 \mathrm{~nm}$ instead of refraction index detector. ${ }^{17,18}$ Owing to the fact that some compounds analysed have the same refraction index of the mobile phase, this detector was regarded as a second choice.

The HPLC analysis was an efficient tool employed to follow up the glycosylation reactions cited above. It allowed the separation and identification of the glycosylated amino acids $3,4,7$ and 8 , and their precursors 5,6 and 9 , based on their different retention times. Once established the ideal HPLC analysis conditions for pure compounds, it was possible to monitor the glycosylation reactions 1 and 2 by assessing the crude reaction mixtures, excluding the necessity of chromatographic column purifications.

\section{Conclusions}

The standardization of HPLC analysis applied to the glycosylated amino acids $3,4,7$ and 8 , and their precursors 5,6 and 9 were described. It was possible to determine the best separation conditions between precursors and final products, involving the suitable detection system, column, mobile phase and flow. Considering that glycosylation reactions lead to the formation of a great number of undesirable by-products, the analysis of the crude reaction mixtures avoids the exhaustive purifications process, necessary to obtain the desired products.

The methodology described represents a contribution for routine analysis of glycosylated amino acids according to the lack of information of HPLC analysis concerned to this class of biological compounds.

\section{Acknowledgments}

The authors acknowledge FAPESP for the financial support and thanks additionally to Prof. Dr. Pierina Sueli Bonato for valuable suggestions.

\section{References}

1. Wong, C-H.; Carbohydrate-based Drug Discovery, $1^{\text {st }}$ ed., Wiley-VCH Verlag GmbH \& Co. KgaA: Weinheim, 2003.

2. Meinjohanns, E.; Meldal, M.; Paulsen, H.; Bock, K.; J. Chem. Soc. Perkin Trans. 1 1995, 5, 405.

3. Zachara, N. E.; Hart, G. H.; Chem Rev. 2002, 102, 431.

4. O’Donnel, N.; Biochim. Biophys. Acta 2002, 1573, 336.

5. Zachara, N. E.; Hart, G. H.; Biochim. Biophys. Acta 2004, 1673, 13.

6. Wells, L.; Vosseller, K.; Hart, G. H.; Science 2001, 291, 2376.

7. Agrellos, O. A.; Jones, C.; Todeschini, A. R.; Previato, J. O.; Previato, L. M.; Mol. Biochem. Parasitol. 2003, 126, 93.

8. Previato, J. O.; Jones, C.; Gonçalves, L. P. B.; Wait, R.; Travassos, L. R.; Previato, L. M.; Biochem. J. 1994, 301, 151.

9. Vandekerckhove, F.; Schenkman, S.; Carvalho, L. P.; Tomlinson, S.; Kiso, M.; Yoshida, M.; Hasegawa, A.; Nussenzweig, V.; Glycobiology 1992, 2, 541.

10. Seeberger, P. H.; Haase, W-C.; Chem. Rev. 2000, 100, 4349.

11. Carvalho, I.; Scheuerl, S. L.; Kartha, K. P. R.; Field, R. A.; Carbohydr. Res. 2003, 338, 1039.

12. Banoub, J.; Chem. Rev. 1992, 92, 1167.

13. Meinjohanns, E.; Meldal, M.; Bock, K.; Tetrahedron Lett. 1995, $36,9205$.

14. Saha, U. K.; Schmidt, R. R.; J. Chem. Soc., Perkin Trans. 1 1997, 12, 1855.

15. Collins, C. H.; Braga, G. L.; Bonato, P. S.; Introdução a Métodos Cromatográficos, $4^{\text {th }}$ ed., Unicamp: Campinas, 1990.

16. Fuji, K.; Ichikawa, K.; Node, M.; Fujita, E.; J. Org. Chem. 1979, 44, 1661.

17. Ciola, R.; Fundamentos da Cromatografia a Líquido de Alto Desempenho, $1^{\text {st }}$ ed., Edgard Blucher: São Paulo, 1998.

18. Navickiene, S.; Ribeiro, M. L.; Quim. Nova 2004, 27, 744.

Received: February 14, 2005

Published on the web: April 28, 2006

FAPESP helped in meeting the publication costs of this article. 